Section Editor

John J. Millichap, MD

Teaching Neurolmages:

\title{
Bilateral intracerebral hemorrhage in expanded dengue syndrome
}

Figure Bilateral intracerebral hemorrhage
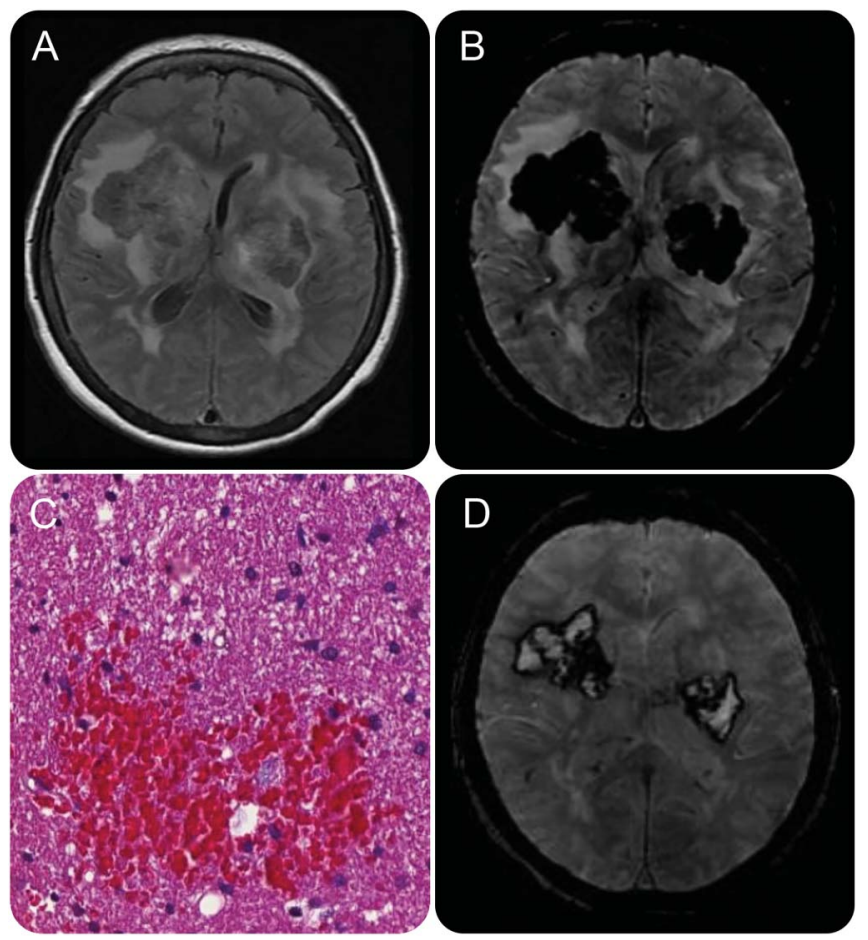

Correspondence to

Dr. Palmeira Cavalcante:

wagner_cid@hotmail.com

Download teaching slides: Neurology.org

Brain fluid-attenuated inversion recovery MRI (A) and susceptibility-weighted imaging (SWI) (B) show large basal ganglia hemorrhagic lesions, vasogenic edema, and mass effect. Brain biopsy (C) demonstrates an area of recent hemorrhage in the subcortical white matter associated with neuropil vacuolization and glial reactivity (hematoxylin $\&$ eosin, $\times 100$ magnification). Follow-up brain MRI SWI (D) reveals substantial reabsorption of bleeding.

A 66-year-old Brazilian woman presented with fever, malaise, and myalgia, followed 10 days later by left hemiparesis and altered mental status. Brain MRI revealed bilateral intracerebral hemorrhages (figure, A and B) and CSF showed mild lymphocytic pleocytosis. Serologic testing for dengue fever was positive. Brain biopsy demonstrated nonspecific inflammatory changes and areas of recent hemorrhage and necrosis (figure, C). After 1 month, partial clinical and radiologic improvement occurred (figure, D). Expanded dengue syndrome ${ }^{1}$ refers to atypical manifestations of dengue such as intracerebral hemorrhage, which is a rare presentation usually reported a week after fever onset, possibly related to release of cytokines with vasogenic activity. $^{2}$

\section{AUTHOR CONTRIBUTIONS}

Dr. Palmeira Cavalcante: study concept and design. Dr. Neto: study concept and design. Dr. Grativvol: study concept and design. Dr. Spera: study concept and design. Dr. Frassetto: study supervision. Dr. Lucato: study supervision. Dr. Nitrini: study supervision.

\section{STUDY FUNDING}

No targeted funding reported.

\section{DISCLOSURE}

The authors report no disclosures relevant to the manuscript. Go to Neurology.org for full disclosures.

\section{REFERENCES}

1. Assir MZ, Jawa A, Ahmed HI. Expanded dengue syndrome: subacute thyroiditis and intracerebral hemorrhage. BMC Infect Dis $2012 ; 12: 240$.

2. Carod-Artal FJ, Wichmann O, Farrar J, Gascón J. Neurological complications of dengue virus infection. Lancet Neurol 2013; 12:906-919.

From the Hospital das Clínicas da Faculdade de Medicina da Universidade de São Paulo, Brazil. 


\section{Neurology}

\section{Teaching NeuroImages: Bilateral intracerebral hemorrhage in expanded dengue syndrome}

Wagner Cid Palmeira Cavalcante, Herval Ribeiro Soares Neto, Ronnyson Susano Grativvol, et al.

Neurology 2017;89;e54

DOI 10.1212/WNL.0000000000004181

\section{This information is current as of July 31, 2017}

\section{Updated Information \& Services}

Supplementary Material

\section{References}

Subspecialty Collections

Permissions \& Licensing

Reprints including high resolution figures, can be found at: http://n.neurology.org/content/89/5/e54.full

Supplementary material can be found at: http://n.neurology.org/content/suppl/2017/07/31/WNL.0000000000004 181.DC1

This article cites 2 articles, 0 of which you can access for free at: http://n.neurology.org/content/89/5/e54.full\#ref-list-1

This article, along with others on similar topics, appears in the following collection(s):

Intracerebral hemorrhage

http://n.neurology.org/cgi/collection/intracerebral_hemorrhage MRI

http://n.neurology.org/cgi/collection/mri

Viral infections

http://n.neurology.org/cgi/collection/viral_infections

Information about reproducing this article in parts (figures,tables) or in its entirety can be found online at:

http://www.neurology.org/about/about_the_journal\#permissions

Information about ordering reprints can be found online:

http://n.neurology.org/subscribers/advertise

Neurology ${ }^{\circledR}$ is the official journal of the American Academy of Neurology. Published continuously since 1951, it is now a weekly with 48 issues per year. Copyright (O 2017 American Academy of Neurology. All rights reserved. Print ISSN: 0028-3878. Online ISSN: 1526-632X.

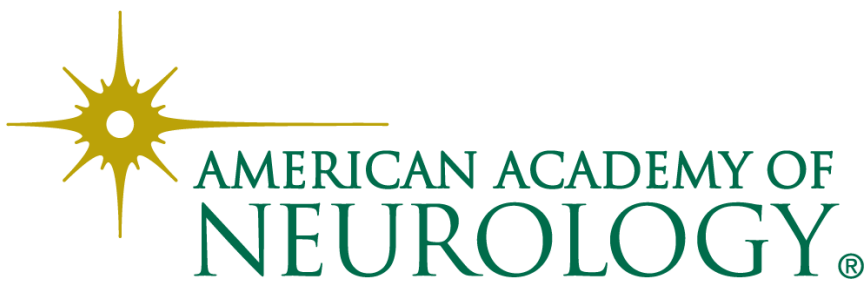

